\title{
TBM TUNNELING ON THE YUCCA MOUNTAIN PROJECT
}

\author{
by James P. Morris and William $\mathrm{H}$. Hansmire \\ Construction Manager, Kiewit Construction Company \\ Las Vegas, Nevada \\ Vice President, Parsons, Brinckerhoff, Quade \& Douglas, Inc. \\ Las Vegas, Nevada
}

\begin{abstract}
The U. S. Department of Energy's (DOE) Yucca Mountain Project (YMP) is a scientific endeavor to determine the suitability of Yucca Mountain for the first long-term, high-level nuclear waste repository in the United States. The current status of this long-term project from the construction perspective is described. A key element is construction of the Exploratory Studies Facility (ESF) Tunnel, which is being excavated with a $7.6 \mathrm{~m} \mathrm{(25 \textrm {ft } )}$ diameter tunnel boring machine (TBM). Development of the ESF may include the excavation of over $15 \mathrm{~km}(9.3 \mathrm{mi})$ of tunnel varying in size from 3.0 to $7.6 \mathrm{~m}$ (10 to $25 \mathrm{ft}$ ). Prior to construction, extensive constructability reviews were an interactive part of the final design. The intent was to establish a constructable design that met the long-term stability requirements for radiological safety of a future repository, while maintaining flexibility for the scientific investigations and acceptable tunneling productivity.
\end{abstract}

\section{INTRODUCTION}

\section{Project Description}

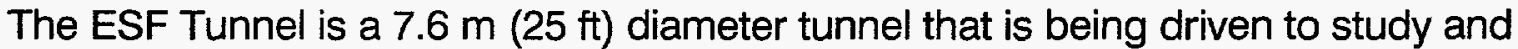
characterize Yucca Mountain in order to determine its suitability to be a repository for nuclear waste. The current work at Yucca Mountain has supplanted all other past activities for potential nuclear waste repository sites in other states. The project is located $160 \mathrm{~km}$ (100 mi) northwest of Las Vegas, Nevada and is situated on the southwest boundary of the Nevada Test Site (NTS). No nuclear weapons testing has been conducted in the area. For the official concepts of the ultimate repository as they have been developed to date, see TESS (1994).

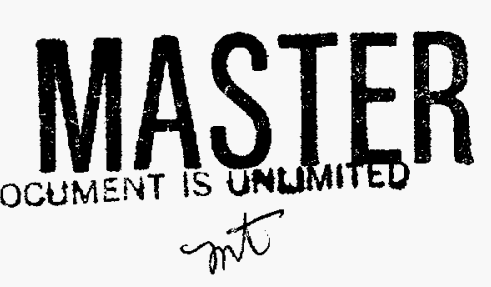




\section{DISCLAIMER}

This report was prepared as an account of work sponsored by an agency of the United States Government. Neither the United States Government nor any agency thereof, nor any of their employees, make any warranty, express or implied, or assumes any legal liability or responsibility for the accuracy, completeness, or usefulness of any information, apparatus, product, or process disclosed, or represents that its use would not infringe privately owned rights. Reference herein to any specific commercial product, process, or service by trade name, trademark, manufacturer, or otherwise does not necessarily constitute or imply its endorsement, recommendation, or favoring by the United States Government or any agency thereof. The views and opinions of authors expressed herein do not necessarily state or reflect those of the United States Government or any agency thereof. 


\section{DISCLAIMER}

Portions of this document may be illegible in electronic image products. Images are produced from the best available original document. 
Figure 1 illustrates the ESF Tunnel to be driven. Major parts of the tunnel work are as follows: The North Ramp is to be driven at about a $2 \%$ downgrade to reach the geologic formation of interest, a subunit of the Topopah Spring tuffs. A $60 \mathrm{~m}(197 \mathrm{ft}$ ) starter tunnel for the TBM was constructed by drill and blast in 1993. The Main Drift crosses the Topopah Spring rocks that would be the eventual repository location. The drive is completed by coming out of the mountain via the South Ramp, exiting at a modest portal structure that has yet to be designed. The whole loop is about $7600 \mathrm{~m}(25,000 \mathrm{ft})$. As of the beginning of January 1995, the TBM was about $40 \mathrm{~m}$ (140 ft) beyond the starter tunnel.

Several alcoves will be constructed for testing purposes and will be done by drill and blast, or possibly by mechanical means. Exploratory drifts will be driven off the main loop to explore geologic conditions. Figure 1 also illustrates drifts off the Main Drift to explore geologic conditions at Ghost Dance Fault and an extension of the North Ramp. This North Ramp extension will determine geologic conditions at the extremities of the potential repository and may provide a location for rock mechanics testing.

Also being considered is a tunnel drive to a lower formation called Calico Hills. Plans

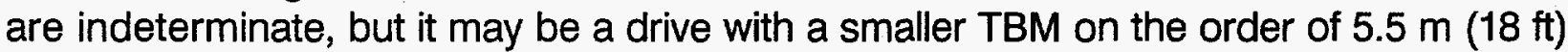
diameter from the North Ramp as shown in Figure 1, or it may possibly be driven from a separate access from the west side of Yucca Mountain. Conceptual plans for this second major tunnel are expected to be established in late 1995.

\section{Geologic Conditions}

Tunneling is through volcanic rocks comprised of welded and nonwelded tuffs. For the initial tunnel drive, the North Ramp, tunneling is against the fairly flat lying rock beds that dip $2^{\circ}$ to $15^{\circ}$ to the east. At least two major fault structures are anticipated. One near the North Portal, the Bow Ridge Fault, has a graben structure that is filled with substantially weaker tuffaceous material than expected for all other tunneling. This material is characterized as a very weak, friable rock, in a sense like a cemented coarse-grained soil.

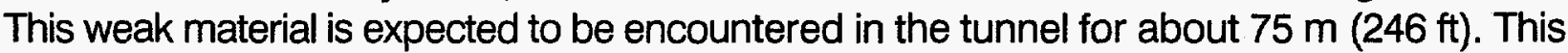
tunneling interval is expected to be essentially soil tunneling having an unconfined compressive strength on the order of $x x \mathrm{Mpa}(0.2 \mathrm{ksi})$. Deeper in the mountain, Drill Hole Wash Fault is expected to be a major geologic structure. Rock strengths are expected to vary from $x x x$ to $x x \mathrm{Mpa}(25 \mathrm{ksi})$. The tunnel is wholly above the ground water table and any significant water inflow is expected only from perched conditions. For more detail on geology, see Buesch, et al (1994).

\section{TBM Selection and Description}

In the spring of 1993 , Construction Tunneling Services (CTS) was awarded an approximately $\$ 13$ million contract for the $7.6 \mathrm{~m}(25 \mathrm{ft})$ diameter TBM and trailing gear. The specifications for the TBM were provided by the YMP Architect Engineer (A/E). The 
specifications were performance based with a major emphasis on minimizing the potential for oil spills. The TBM and trailing gear are shown in Figure 2.

The TBM designed and built by CTS is a shuffle shoe machine. The shuffle shoe machine differs from the typical main beam machine in how it propels. This machine has four large grippers that work in sets of two, a horizontal and vertical set. The two sets of grippers "float." The two shoes of each set are tied together by four gripper cylinders and tied to the cutterhead/forward shield with two propel cylinders on each shoe. The grippers are not connected to any frame work on the TBM.

The two sets of grippers can either be operated independently (shuffle shoe mode) or in combination (full grip mode). When in the shuffle shoe mode, each set of grippers alternates between propel and retract, providing a continuous mining operation. The full grip mode is used when ground conditions require the additional gripper load or thrust provided by the eight propel cylinders. This mode would be expected in the weak materials beyond the Bow Ridge Fault.

Specific details of the TBM are given in Table 1. The cutterhead is driven by 12 twospeed electric motors, each connected to an air-operated clutch and planetary speed reducer. The two-speed motors are water cooled and operate at 1800 and $900 \mathrm{rpm}$. The cutterhead main bearing is $4110 \mathrm{~mm}$ (162 in) in diameter.

The cutterhead drive seal system consists of an inner and outer seal assembly. Each seal assembly consists of three lip-type rotary seals. The inner most seal has the lip facing inward to contain oil while the middle and outer seals have the lips facing outward to inhibit dirt from entering the drive cavity. The area between the middle and outer seals is connected to a water source. This arrangement provides lubrication of the seals while flushing dirt from the seal area. This design was influenced by the requirement to reduce hydrocarbon leaks (see section herein on "Items of Special Importance").

\section{Contract}

Different from most major tunneling projects, the ESF Tunnel construction contract is on a cost plus contractual basis. Funding is subject to an annual congressional appropriation, so the timing and amount of tunnel work done or equipment and materials procured are not within the strict control of the constructor. Rather, management of YMP sets priorities and goals, and funding needs and allocations are projected and revised as the project moves forward. Allowable costs and fees are set by the U.S. Government procurement regulations. 


\section{KEY REQUIREMENTS FOR ESF TUNNEL}

\section{Items of Special Importance}

The ESF Tunnel may become part of an eventual nuclear waste repository. The design and construction are strongly influenced by this possibility. The broad requirements on what is built come from federal regulations and a series of implementing documents that have developed over the years. Closest to actual construction are the final specifications and drawings that determine the work to be done. In the development of the specifications and drawings, a determination of importance evaluation (DIE) takes place. The DIE gives special requirements for the design and resulting construction.

The DIE considers three major areas. The first area, waste isolation, is the impact in which the capability of the site to isolate nuclear waste is evaluated. An example of this type of concern is for organic materials used in tunnel construction. This concern drove the design to minimizing use of any organics (like timber lagging behind steel sets) and an extensive leak mitigation system for the TBM hydraulics (the hydraulic fluids are generally hydrocarbons). Another notable outcome of this DIE concern is the prohibition on rock bolts grouted with epoxy resin, which is organic. A major impact, which is not discussed at length in this paper, is the limitations on use of diesel-powered locomotives. If diesel exhaust is finally deemed a problem, an electric trolley transportation system is planned to be installed. The project is in a testing mode to determine real diesel impacts.

Of more general concern for waste isolation is a requirement to prevent preferential pathways for migration of radionuclides. This could occur if the tunnel is considered to be a hole surrounded by more than naturally fractured rock. A man-made barrier might be constructable across the tunnel hole made by the TBM, but the surrounding rock would remain as a possible preferential pathway. This concern in part leads to strict controls on ground support and is discussed in the following section.

A second DIE concern is for radiological safety. This involves tunnel stability and safety at a future time if nuclear materials were being transported through tunnels built as part of the ESF. Because of the high concerns for safety when nuclear materials are involved, the tunnel ground support system has been given special attention in design and construction (see section Quality Assurance).

Finally, a third DIE concern is for impacts on geotechnical and geologic testing. The mission of the ESF Tunnel is to determine site conditions so construction cannot unduly prohibit the intended scientific investigations. One outcome of this concern is that cementgrouted rock bolts cannot be used in areas where testing is to take place, such as for rock permeability. Grout running unpredictably through rock fractures in an area of such testing could not be tolerated. Shotcrete is generally discouraged to allow for geologic mapping. Shotcrete is in the design, but in general, the project envisions relying on rock bolts and 
welded wire fabric for ground support, with shotcrete as an alternative only if necessary. In order to permit geologic mapping, some ground support is deferred in the construction sequence, but not to the extent that unsafe working conditions are created.

\section{Quality Assurance}

The ESF Tunnel is being designed and constructed with a quality assurance (QA) program like that required for nuclear power plants. Major impacts to the conduct of design and construction have resulted. Only the portions of the ESF Tunnel that have some relevance to future nuclear safety are involved. Tunnel excavation per se is not subject to QA controls. On the other hand, tunnel ground support is a QA-controlled item. Thus, the ground support design is done with extensive and fully documented reviews. Procurement of ground support materials requires lifetime documentation and traceability from materials used in manufacturing (like the steel in the steel sets) to fully inspected installations according to written procedures. Record keeping is thorough, precise, and subject to internal and external audit for conformance to specifications and procedures. Personnel are qualified for their specific jobs throughout the construction organization from tunnel supervision to quality control inspection. No other tunnel has had this QA requirement. Nevertheless, designs have been made and with substantial effort, tunneling is under way with a nuclear QA program in place.

\section{Schedule}

Schedule is a major driving requirement. The DOE intends to make a determination of technical site suitability by the year 1998 (DOE, 1994). Thus, the sooner the tunnel is completed, the better. Both design and construction are working to meet this schedule demand. As of the end of 1994, only the North Ramp had a final design. Designs were starting for the Main Drift across the repository horizon and the ramp out of the mountain to the South Portal. Other major decisions remain to be made. These decisions include the need for and layout of exploratory drives to investigate known or suspected faulted areas and boundaries of the Topopah Spring Formation and tunneling to the lower Calico Hills Formation.

The extraordinary requirements on the tunnel design and construction are in conflict with the idea of maximum tunnel progress. Constructability of the tunnel has focused on finding solutions to mitigating impacts of special and extraordinary ESF requirements on the ability to construct the tunnel as fast as possible. 


\section{TUNNEL CONSTRUCTABILITY ISSUES}

\section{Ground Support}

Ground Support was recognized as a key factor in TBM productivity. In conventional tunneling, the minimum ground support for short-term, initial conditions for safety are required during tunnel excavation. A final tunnel lining is installed later.

For the ESF Tunnel, substantially different constraints and conditions were present. The final ground support system is required to be installed as the tunnel progresses. Further, there are several restrictions on the materials that could be used in the ground support system. The need for these restrictions resulted from the following requirements:

-100-year maintainable life to maintain tunnel integrity for future retrievability of stored nuclear waste, if a repository is constructed. This drove the design to grouted rock bolts for long-term permanence.

- Restriction on organics and waste isolation have dictated extreme limitations on anything organic. This restriction barred the use of epoxy resin-grouted rock bolts or dowels and timber blocking for structural steel ground supports (steel sets).

- Immediately verifiable safety involving a bolt that can be tested immediately. A rock bolt with a mechanically set anchor or friction-type rock bolts like Swellex or split-sets meet this criterion. On the other hand, a cement-grouted bar was not acceptable.

On this project, rock bolts is the general term used to refer to all rock reinforcement such as Williams rock bolts, Swellex rock bolts, split-sets, or fully-grouted re-bar.

The resulting design is shown in Figure 3. Fully-grouted Williams rock bolts in a pattern on nominal $1.5(5 \mathrm{ft})$ centers is shown. For poorer ground conditions, steel sets were designed as shown in Figure 4.

Constructability had a big part in establishing the ground support installation procedure. Only 6 of the pattern rock bolts can be installed by the drills at the TBM. This results from two factors. One, the drills have limited reach about the tunnel periphery and thus, cannot drill directly in the tunnel crown or at the sidewalls. Second, if all rock bolts were placed immediately behind the TBM, tunnel advance rate would be seriously reduced. When the additional trailing floor was added for the mapping gantry, two more drills were added to complete the ground support installation. 


\section{Geologic Mapping}

The ESF Tunnel will be geologically mapped in its entirety and some major constraints exist for fulfilling this mission. The geologic information must be collected as soon as possible that on-going assessments can be made. Thus, the geologic mapping must be done contemporary with the tunneling. Geologic mapping cannot be done after hole through. Also, since ground support will either in part or in whole mask the geology, mapping must be done at some time in the ground support process. Ideally from the geologists' perspective, mapping should be done at the tunnel heading, which in this case is immediately behind the TBM tail shield.

The solution to performing detailed geologic mapping during tunneling was to add additional trailing gear with a mapping gantry to the TBM backup system. See Figure 2 for the general layout and Figure 5 for a detail of the mapping gantry. In the initial thinking in 1993 , it was thought that this mapping gantry could operate independently behind the TBM trailing gear. It became apparent when the tunnel constructor came on the project that geologic mapping like what was expected would not be possible in such an arrangement. All ground support would be in place, which would likely include welded wire fabric, channel, and possibly shotcrete. Further, the fan line, conveyor, and other tunnel utilities would be in place.

The additional trailing floor with mapping gantry permits mapping before all utilities are in place. Key points are as follows: rock cleaning with an air-water mist is accomplished just before mapping on a drill/cleaning platform at the front of the additional trailing floor. The drill station is located at the front of the additional trailing floor. For safety reasons, it was considered necessary to make final rock bolt installation at this location before the geologic mapping.

The geologic mapping gantry has its own electric drives and rides on its own set of rails on the trailing floor. The gantry platforms provide access for a geologist to inspect the rock directly. At the front of the gantry, a variable height catwalk supports a camera. With the catwalk down and the camera at the tunnel springline, the available periphery of the tunnel will be photographed in stereo pairs (approximately $270^{\circ}$ ). The catwalk is raised to permit transportation of invert segments and ground support materials to the heading. The mapping gantry travel length is $46 \mathrm{~m}$ (150 ft), which is roughly based on theoretical maximum tunneling for 2 shifts. If no mapping is done during tunneling, the current length of tunnel that became available could be physically accessed and photographed from the gantry that moved on its own, while the TBM was idle for maintenance. In an alternate mode of operation, horizontal jacks are intended to hold the mapping gantry steadily in place and in theory permit photography during tunneling. Shakedown of the whole mapping gantry system remains to take place. 
Although the TBM with complete backup was already in procurement and scheduled for delivery in April 1994, it was decided in 1993 to proceed with procurement of the additional trailing gear with mapping gantry and add it to the TBM backup. The TBM was fully assembled by August 1994. Limited tunneling was undertaken by the end of November 1994. In December 1994, the additional trailing floor was installed. As of writing of this paper, tunneling had not progressed to where the mapping gantry had been used.

\section{Leak Mitigation/Minimization of Hydrocarbons}

As described earlier, the concern for hydrocarbons drives many aspects of the design. For the entire project, extensive record keeping tracks what materials are left in the tunnel. All materials used are given scrutiny. If something else can be reasonably used, design and construction are to conform. An example is the use of steel lagging and blocking instead of timber.

A special effort was made to procure a TBM that had the prevention, or minimization, of hydraulic leaks as a requirement. This leak mitigation effort had many manifestations. The TBM cutterhead drive motors are electric, not hydraulic, to eliminate a substantial amount of hydraulic equipment use. Hoses on the other TBM hydraulic equipment have a program for changeout to result in replacement before failure. Hydraulic couplings have the ability to bleed high-pressure fluids without creating a spill when being repaired or maintained. Hydraulic hoses in general are furnished with pressure ratings substantially higher than operating levels in order to give an additional margin of safety from failure.

In an ironic twist regarding minimizing hydrocarbons lost in the tunnel, pneumatic rock drills that typically operate with oil in the compressed air are generally not to be used. Thus, the 4 large drills for ground support had to be hydraulic and inherently impose some risk of hydrocarbon leaks. For special situations, provisions were made to use pneumatic air-leg drills or stopers where hydraulic drills are not available.

\section{Utilities}

The ESF Tunnel construction is fundamentally faced with attempting to build a completed tunnel as it goes with the full, permanent utilities brought in behind the TBM trailing gear. "Permanent" in this case means several years (on the order of 15 years) of ESF Tunnel use for site investigations including in-situ testing. Even though this is not to be a public transportation tunnel, the ESF Tunnel has substantial ventilation, water supply, waste water discharge, compressed air, instrumentation and controls, and electrical systems to support ESF Tunnel testing activities that will start during tunneling and continue for some time after tunneling is completed. All of these utilities greatly exceed the requirements, or are not needed at all in the case of instrumentation and controls for tunneling. Typical utilities are shown in Figure 6. 
The constructability of each utility system was addressed separately. Air, water supply, and discharge piping will be installed without major impact behind the TBM trailing gear. Supports to the tunnel wall are simple. The water supply for fire protection is larger than normally required and has been down sized from initial design.

The ventilation system is sized to have flexibility to accommodate future tunnel configurations, which have not been entirely decided. Ventilation fans operating at $x x \mathrm{hp}$ at $x x$ in.w.g. on $x \times m(1700 \mathrm{ft})$ intervals may be spaced out if field measurements of air flow justify such a change. Substantial savings in construction cost and tunneling schedule can be realized if less fans are installed.

The electrical system posed some special concerns for constructability. Redundant electrical feeds with heavy armored cable for safety is the design. The design further assumed a full length walkway on the right rib of the tunnel. Where mine power centers were required (at each fan), the electrical equipment was designed to be in a niche, or alcove, in the tunnel sidewall. A tidy arrangement resulted where the walkway would not be interrupted at electrical equipment that might stretch for $17 \mathrm{~m} \mathrm{(50} \mathrm{ft)} \mathrm{along} \mathrm{the} \mathrm{tunnel.}$ Constructing this electrical alcove was demonstrated to have dramatic impact on tunnel progress. A drill and shoot operation would be required and transportation to service the TBM would have to be halted. To keep power to the TBM, each alcove would have to be excavated and the equipment installed in series with tunneling. With the large number of alcoves envisioned, several months time to excavate the Topopah Spring Loop would be required for just the alcoves. The constructability mitigation recommendation was to remove the walkway and eliminate the electrical niches. The electrical equipment could be supported low on the sidewall and still maintain the transportation clearance required. The project is seriously considering this change.

\section{CONCLUSIONS}

The special nature of the ESF Tunnel for the YMP has resulted in tunnel construction without precedent. The unique concerns for future radiological safety and nuclear waste isolation have had dramatic impacts on design and constructability.

The project has had significant impacts from the combined factors of project funding, government procurement procedures, and the inherent uncertainty with the exploratory mission. Thus, the project has a difficult task to adapt to changes when there are such long lead times for procurement, particularly for major equipment. This is a markedly different situation from traditional fixed price tunnel construction contract where the scope of the work is a given condition and procurement is wholly the responsibility of the construction contractor. 
A substantial learning curve is to be expected for each new phase of work which has no precedent. With the design involving many aspects usually in the control of the construction contractor, such as temporary ground support and construction utilities, two entities, not one, must undergo a substantial transition period where the work is started as intended and then refinements are made to design and construction.

\section{ACKNOWLEDGEMENTS}

Reynolds Electrical and Engineering Co., Inc. (REECo) is the contractor for the NTS. Under the current contractual arrangement with DOE, REECo is the construction participant for YMP. In 1993, REECo awarded Kiewit Construction Company's Underground District the contract for the underground construction of the ESF Tunnel. Parsons, Brinckerhoff, Quade \& Douglas, Inc. is a subcontractor to Kiewit and is providing quality assurance and technical support. TRW Environmental Safety Systems, Inc. (TESS) is DOE's M \& O contractor for YMP. Under TESS, the architectural engineering (A/E) services for design of the underground portions of the ESF Tunnel were primarily done by staff from MorrisonKnudsen (MK).

\section{REFERENCES}

Buesch, D. C., Dickerson, R. P., Drake, R. M., and Spengler, R. W., 1994, Integrated Geology and Preliminary Cross Section Along the North Ramp of the Exploratory Studies Facility, Yucca Mountain, Proceedings of the Fifth Annual International Conference, HighLevel Waste Management, Las Vegas, ASCE and ANS, Vol 2, pp. 1055-1065.

Department of Energy, 1994, Five-Year Plan, Fiscal Years 1996-2000, Yucca Mountain Site Characterization Project, Pre-Decisional Draft, October 12.

TRW Environmental Safety Systems, Inc. (TESS), 1994, Initial Summary Report for the Repository/Waste Package Advanced Conceptual Design, Document No. B0000000001717-5705-00015 Revision 00, Prepared for the U.S. Department of Energy, Yucca Mountain Site Characterization Project under Contract No. DE-AC01-91RW00134. 
TABLE 1

\section{GENERAL MACHINE SPECIFICATIONS}

Cutters:

$\begin{array}{ll}\text { Type } & \text { Disc(rear loading) } \\ \text { Number } & 48 \\ \text { Size } & 42-17 \text { inch diameter } \\ & 6-16 \mathrm{inch} \text { diameter } \\ \text { Nominal Cutter Loading } & 55,000 \mathrm{lb} \\ \text { Maximum Cutter Loading } & 65,000 \mathrm{lb}\end{array}$

Thrust System:

Thrust(Continuous Mode)

Thrust(Shuffle Shoe Mode)

Boring Stroke

Maximum Advance

Number of Cylinders

$3,600,000 \mathrm{lb}$
$7,200,000 \mathrm{lb}$
30 inches
$18 \mathrm{ft} / \mathrm{hr}$
8

Gripper System:

Grip Force (Two Shoe)

Grip Force (Four Shoe)

Number of Cylinders

Ground Pressure
$10,054,000 \mathrm{lb}$

$20,108,000 \mathrm{lb}$

8

240 psi

Cutterhead Drive:

Type

Number of Units

Speed Reducers

Clutch

Speed

Power

Torque
Two-Speed Electric, Water-Cooled 12

Two Stage Planetary

Disengage, Air-Actuated

6.6 or $3.3 \mathrm{rpm}$

3,000 hp@6.6rpm

2,386,000 ft/lb @6.6 rpm

3,576,000 ft/lb @ 3.3 rpm

Conveyor:

Drive

Speed

Width

$2 \times 40 \mathrm{hp}$, Electric

$400 \mathrm{ft} / \mathrm{min}$

42 inch

Capacity 
TABLE 1 (Continued)

\section{GENERAL MACHINE SPECIFICATIONS}

Hydraulic System:

\begin{tabular}{|c|c|}
\hline Pump Motors & $\begin{array}{l}2 \text { each, } 100 \mathrm{hp} \\
1 \text { each, } 10 \mathrm{hp}\end{array}$ \\
\hline System Pressure & \\
\hline Grip/Thrust & 4,000 psi \\
\hline Other Circuits & 2,500 psi \\
\hline
\end{tabular}

Electrical System:

Primary Voltage

$12,470 \mathrm{~V}, 3$ Phase

Transformers

2 each, 2,200 kVA 


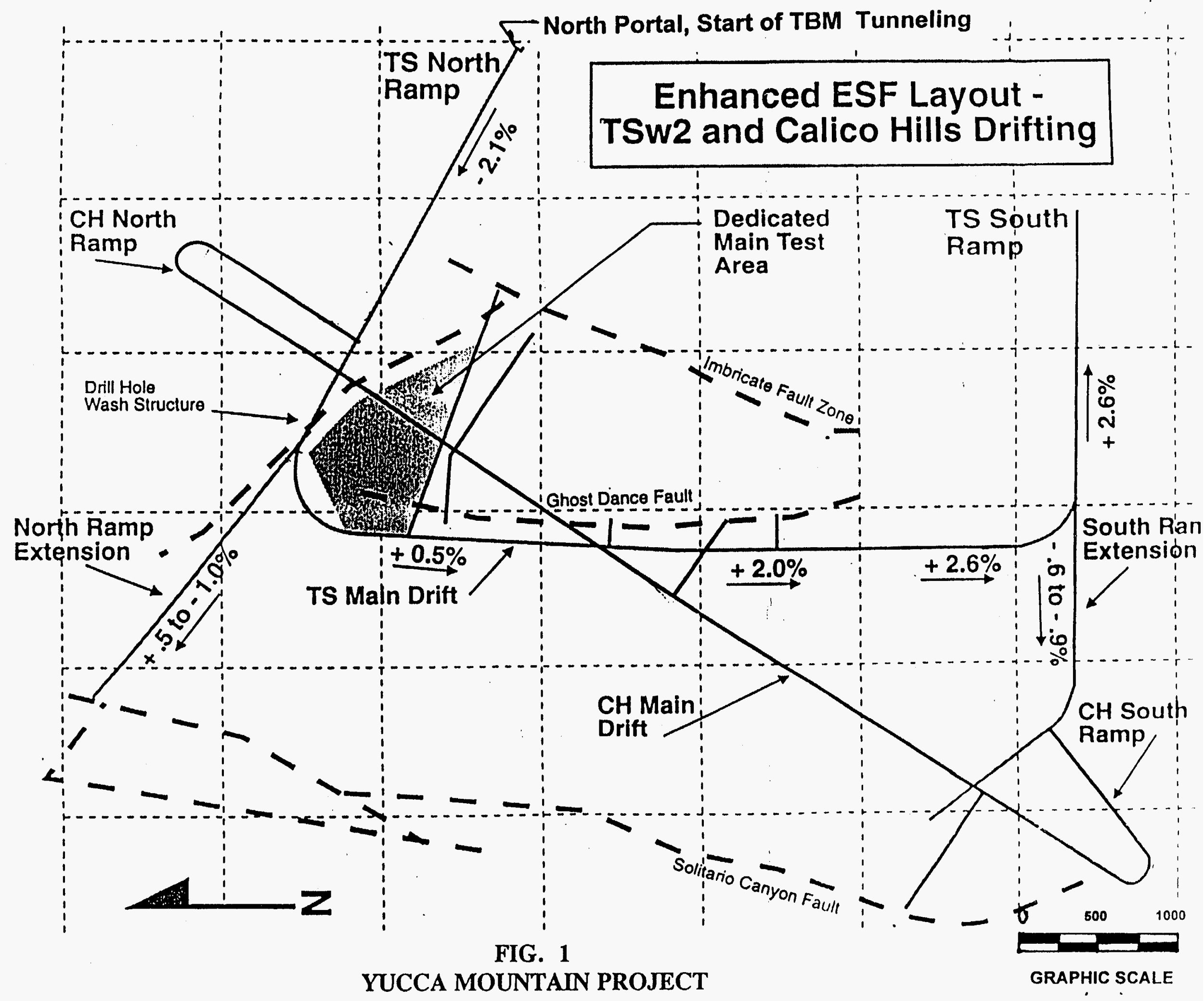




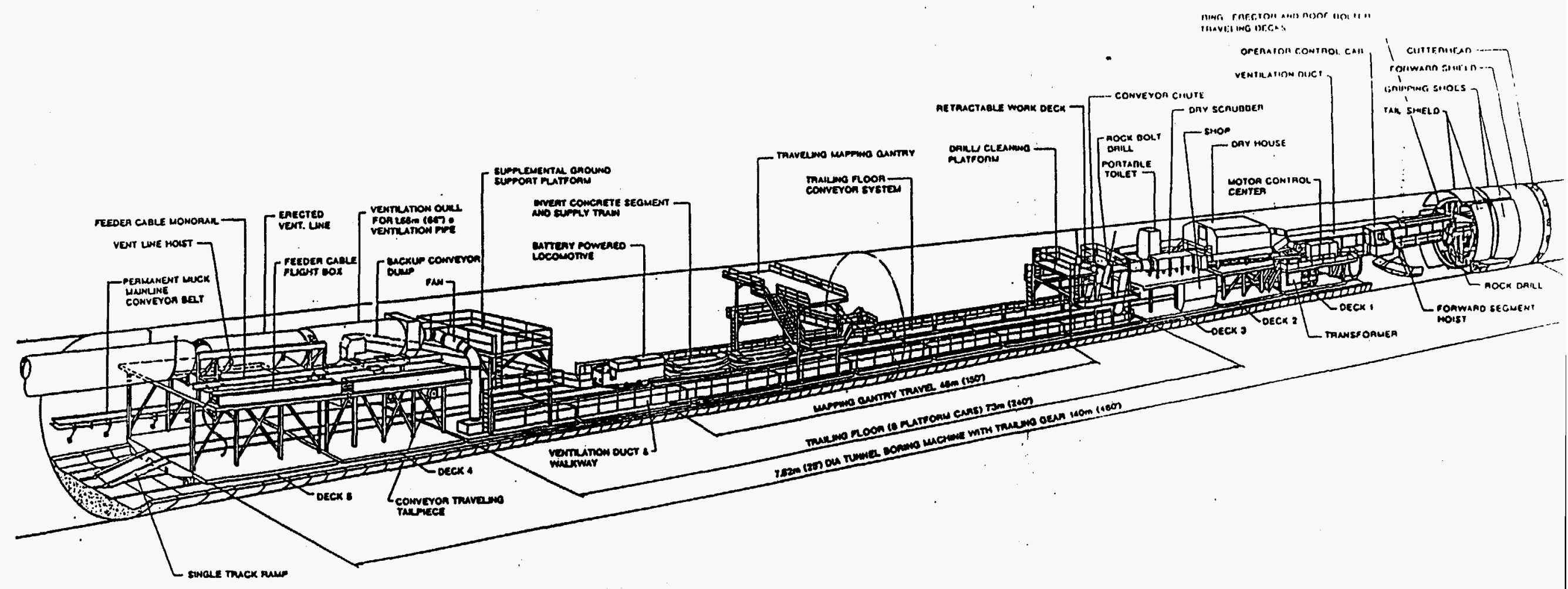

FIG. 2

TBM AND TRAILING GEAR 


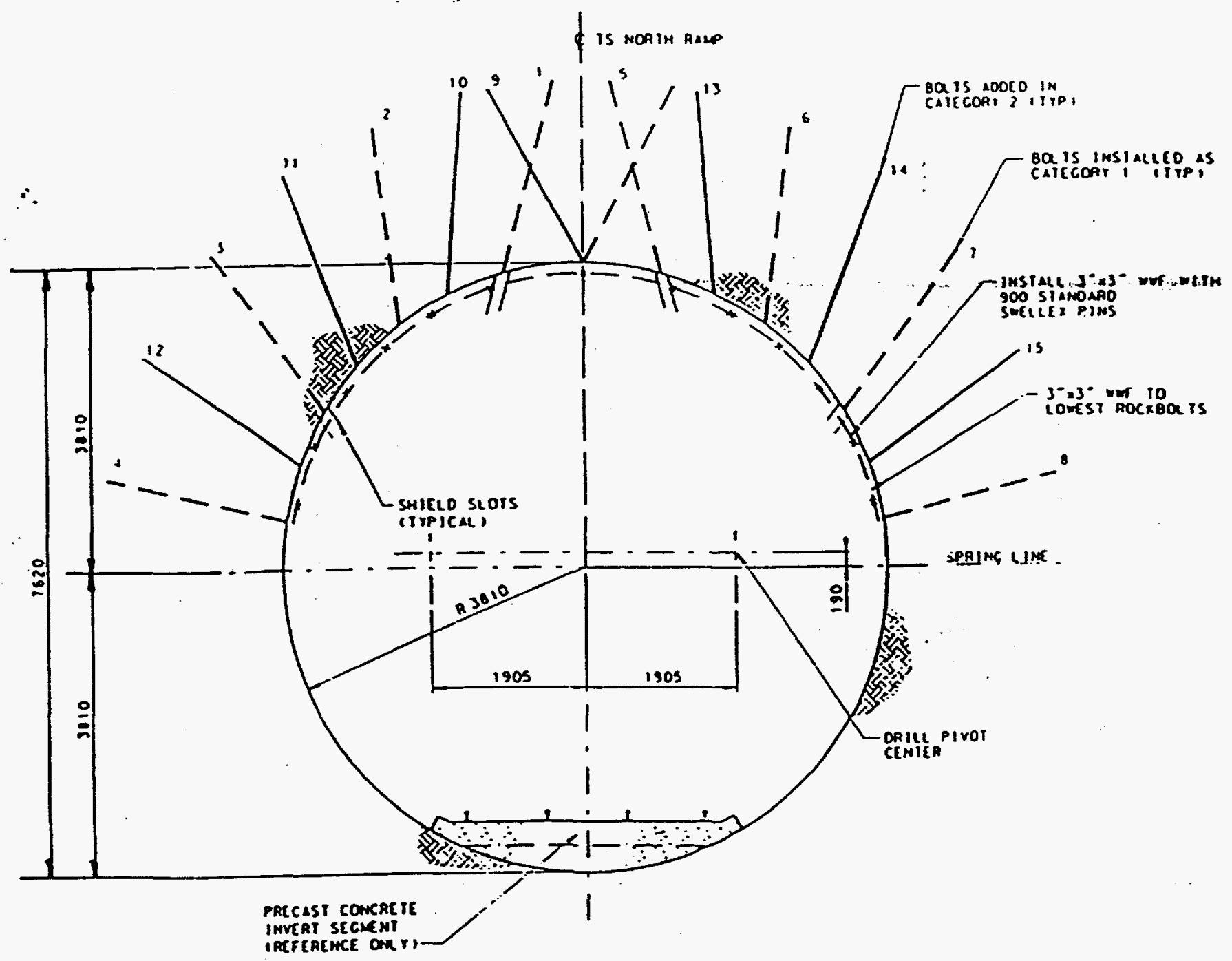

FIG. 3

TYPICAL GROUND SUPPORT DESIGN WITH ROCK REINFORCEMENT 


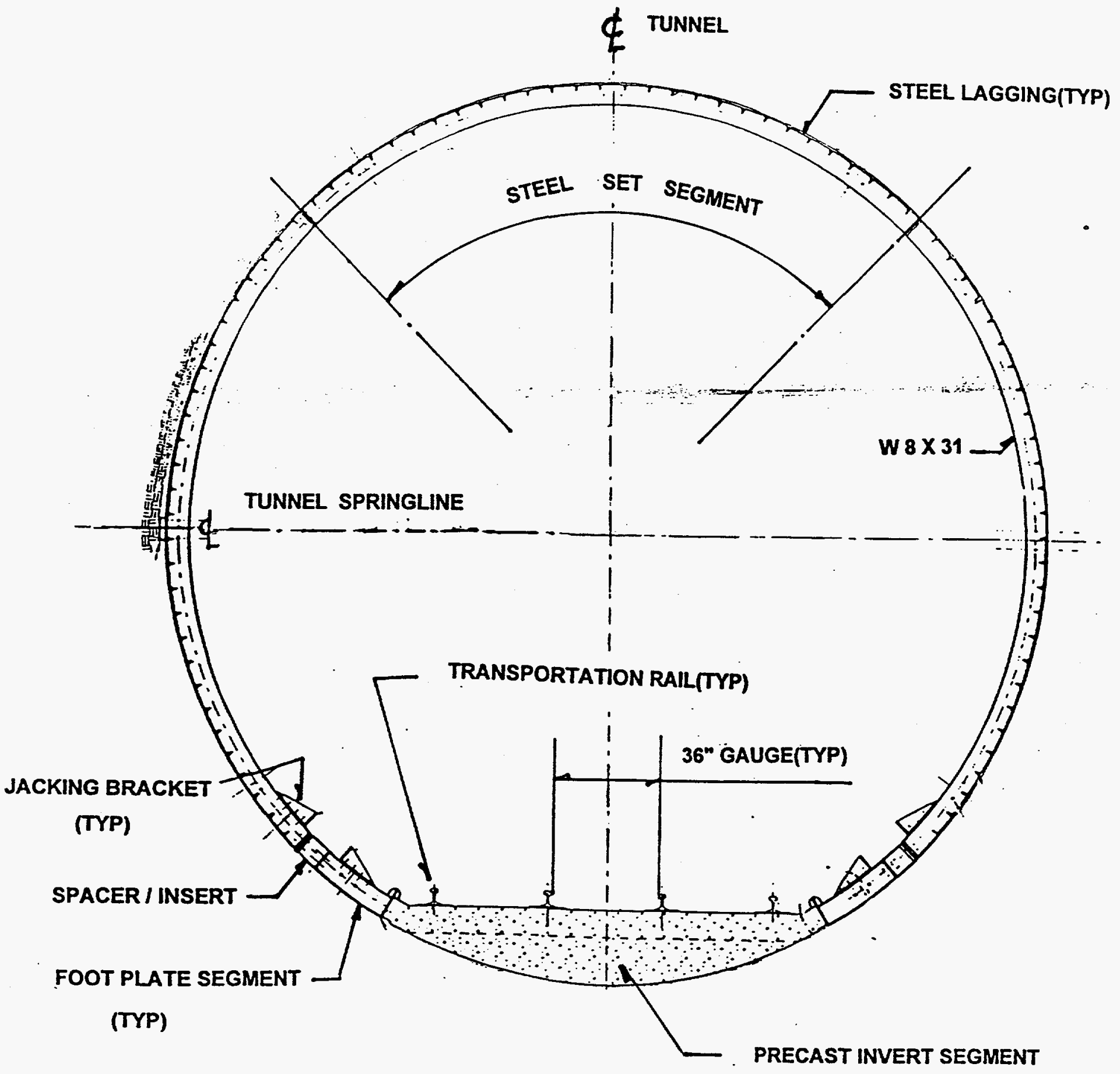

FIG. 4

TYPICAL GROUND SUPPORT WITH STEEL SETS INSTALLED WITH PRECAST INVERT SEGMENTS FOR RAU TRANSPORTATION 


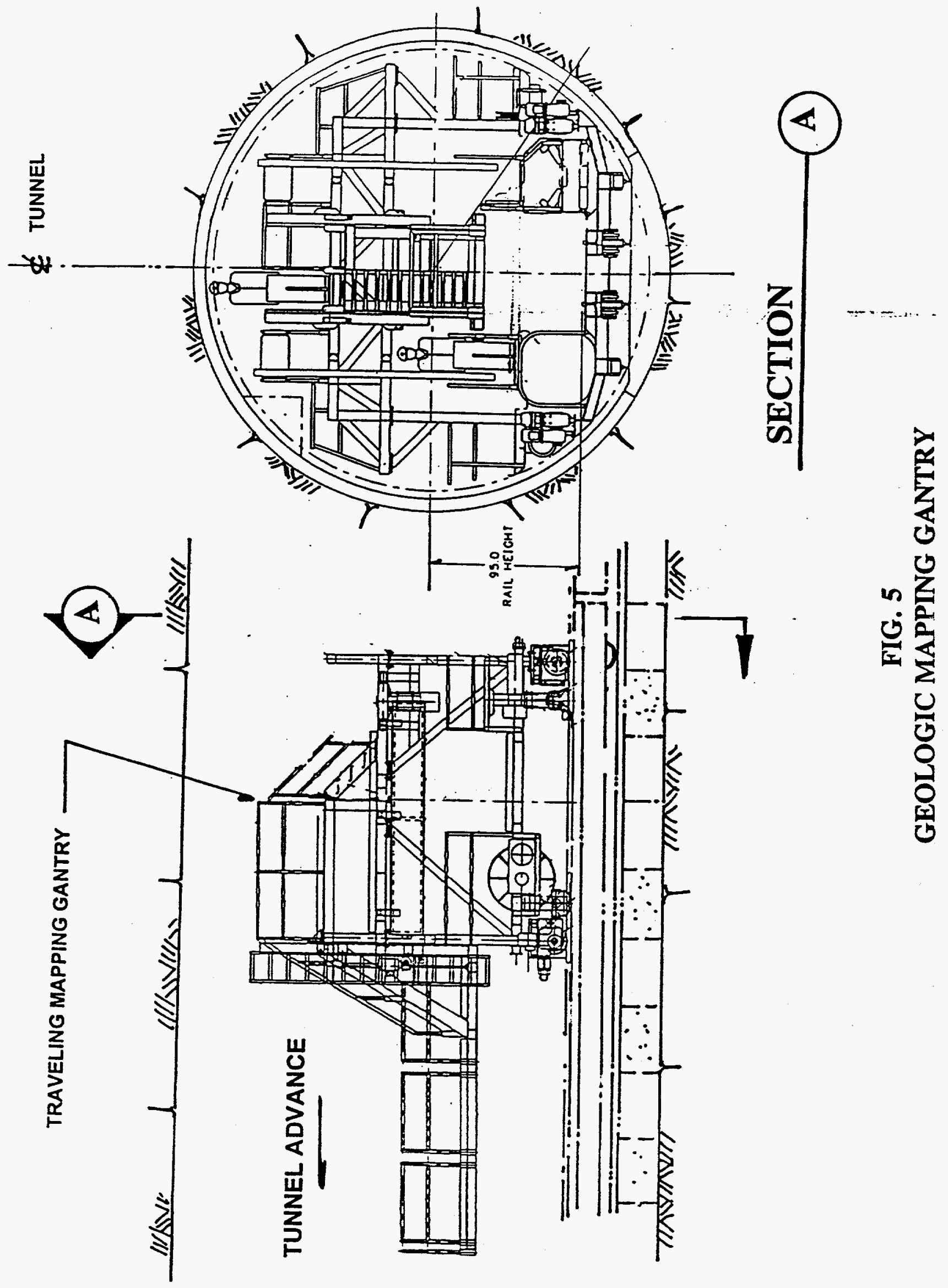




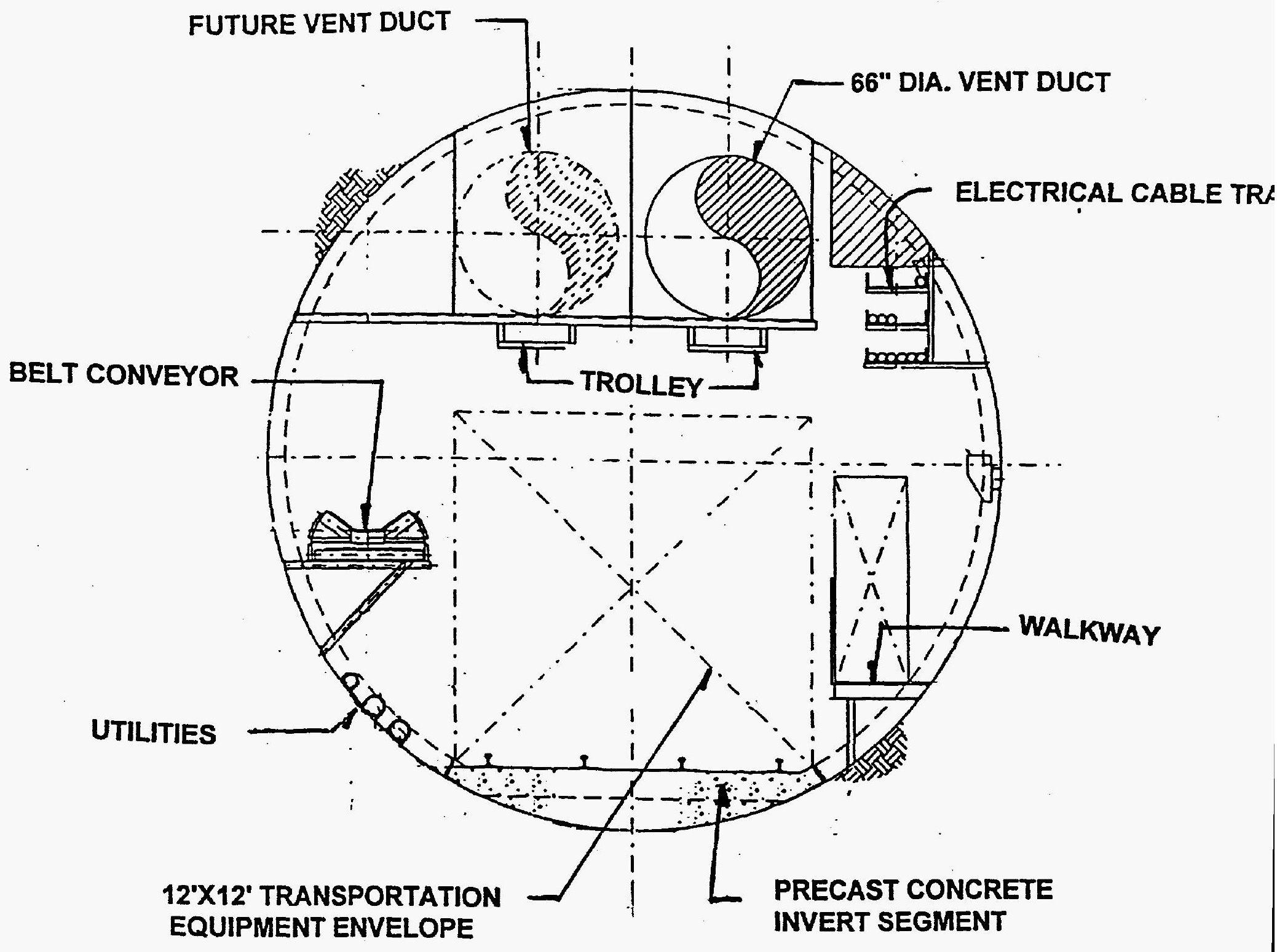

FIG. 6

TYPICAL TUNNEL CROSS-SECTION 